\title{
List of Maps and Plates
}

- MAPS -

1 Sutherland in 1820.

2 Sellar's farms in 1814 and 1831.

\section{- Plates -}

1 The young Sellar (courtesy of Christopher and Valerie Lang of Titanga, Victoria).

2 Sellar in his prime. From a painting by Sir David Macnee, 1851 in E. M. Sellar, Recollections and Impressions (Edinburgh and London 1907). Print courtesy of the Trustees of the National Library of Scotland.

3 Mrs Sellar (1793-1875) (courtesy of Christopher and Valerie Lang of Titanga, Victoria).

4 William Young Sellar (1825-1890), son of Patrick Sellar (courtesy of Christopher and Valerie Lang of Titanga, Victoria).

5 Patrick Plenderleath Sellar (1823-1892), son of Patrick Sellar (courtesy of Christopher and Valerie Lang of Titanga, Victoria).

6 Thomas Sellar (1820-1885), son of Patrick Sellar (courtesy of Christopher and Valerie Lang of Titanga, Victoria).

7 Elizabeth Leveson-Gower, de jure Countess of Sutherland, Duchess/ Countess of Sutherland (1765-1839) by George Romney (with permission from the National Portrait Gallery, London).

8 George Granville Leveson-Gower, First Duke of Sutherland (17581833) by Thomas Phillips (with permission from the National Portrait Gallery, London).

9 Sir Paul Strzelecki (1797-1873) by permission of the State Library of Victoria).

10 James Loch (1780-1855) (with permission from the National Portrait Gallery, London).

11 Stewart of Garth, Major General (1772-1829) by S. W. Reynolds after J.

M. Scrymgeour (with permission from the Scottish National Portrait Gallery, Edinburgh).

12 Dunrobin Castle (with permission from Lord Strathnaver, Dunrobin Castle Limited).

13 Photograph of Patrick Sellar towards the end of his life (courtesy of Christopher and Valerie Lang of Titanga, Victoria).

14 Portrait of Patrick Sellar (courtesy of Justice Robert Fisher of Hahndorf). 